\title{
CHARACTERISTICS OF ANTIBIOTIC-RESISTANT ESCHERICHIA COLI IN THE RECTUM OF HEALTHY SCHOOL-CHILDREN
}

\author{
GUNILLA LIDIN-JANSON*†, E. FALSEN $\dagger$, U. JODAL $* \dagger$, B. KAIJSER $\dagger$ AND \\ K. LINCOLN $\dagger$
}

$\dagger$ Departments of Clinical Bacteriology and Immunity, Institute of Medical Microbiology, and *Departments of Infectious Diseases and Paediatrics, University of Göteborg, Göteborg, Sweden

IN the host-parasite relationship in urinary tract infection (UTI), several characteristics of the invading micro-organism may be of importance (Hanson, 1973). The bowel is an important reservoir for strains of Escherichia coli that infect the urinary tract (Turck, Petersdorf and Fournier, 1962). During the treatment of patients with UTI the selective pressure of antibacterial agents may profoundly influence the gut flora (Winberg et al., 1973). The aim of the present study was to define some characteristics of $E$. coli strains in the faecal flora of a community of school-children and especially to compare the drug-resistant $E$. coli strains with those of normal sensitivity in order to evaluate the selection of drug-resistant strains during antibacterial treatment in domiciliary practice.

\section{MATERIALS AND METHODS}

Plan of the investigation. In connection with a screening programme for asymptomatic bacteriuria in school-children (Lindberg et al., 1975) 774 rectal swabs were taken from 655 children aged 7 to 16 years. Children from four schools (A, B, C and D) in different parts of the city (450 000 inhabitants) were studied-A and B in March 1971, C and D in November 1972, and B and D again in May 1974. In the course of the study, 20 and 96 pupils of schools B and D respectively were examined twice. In each school, classes of 18-31 pupils from each of the first to the sixth or seventh grades were examined. Questionnaires were distributed together with bottles for morning urine specimens. Histories of courses of antibiotics during the previous year, usually in respect of penicillin $\mathrm{V}$, were reported in 136 cases $(17.6 \%)$ and explicitly denied in $612(79.1 \%)$. Nitrite tests and dip-slide cultures demonstrated infection in three cases (Lindberg et al., 1975) and these children were excluded from the present study.

In each school, the pupils had lunch at a canteen. The food was prepared in separate kitchens for each school but supplies came from the same stores.

Bacteriological examinations. Faecal specimens were taken by swabbing the rectum with a cotton-tipped applicator stick which was inserted about $4 \mathrm{~cm}$ from the anal skin surface. Each swab was put into a tube containing transport medium (Möller, 1966), kept at $4^{\circ} \mathrm{C}$ and plated out later the same day. All plates were incubated aerobically at $37^{\circ} \mathrm{C}$ overnight.

Each swab was first used for heavy inoculation of one plate of peptone-free blood-agar. Antibiotic disks (AB Biodisk, Solna, Sweden) were placed on the agar surface. In 1971, new concentrations of certain antibiotics for these standard disks, came into use all over Sweden. The antibiotics and quantities in $\mu \mathrm{g}$ per disk were as follows, the amounts in brackets being those used up to 1971 : sulphasomidine (Su) 250 (2400), tetracycline (T) $30(50)$, streptomycin (S) 30 (50), chloramphenicol (C) 30 (30), ampicillin (A) 10 (12), nitrofurantoin (Ni) 30 (30),

Received 2 Aug. 1976; accepted 23 Dec. 1976.

J. MED. MICROBIOL.-VOL. 10 (1977) 
nalidixic acid (Nal) 30 (30). In 1972 and 1974 trimethoprim (Trim), $1 \cdot 2 \mu \mathrm{g}$ per disk, was also used. The zones of inhibition around the antibiotic disks were measured in mm. Colonies of Gram-negative bacilli growing nearer to the disks than usual for sensitive $E$. coli were picked off for subculture.

The swabs were also cultured on modified Conradi-Drigalski agar plates (Kauffmann, 1966) to produce single colonies. One colony from each plate was subcultured. Selection irrespective of colony morphology was achieved by always picking the last colony growing from the streaks. Gram-negative bacilli were typed according to Edwards and Ewing (1972). Strains were held as deep agar-stab cultures under sterile paraffin oil.

Escherichia coli serotyping. A simplified $O$ grouping was performed on Perspex plates as previously described (Lincoln, Lidin-Janson and Winberg, 1970) but with further development of the technique as follows. In a first step, 10 monovalent sera to the $\mathrm{O}$ antigen groups 1,2 , $4,6,7,8,16,18,25$ and 75 were used. If a distinct agglutination did not occur, two sets of polyvalent antisera were used. Polyvalent antisera to 56 O-groups were produced by immunising altogether 15 rabbits in a crosswise manner, giving one set of seven sera and one set of eight sera, each set containing agglutinins to all 56 O-groups. A strain reacting in both sets could thus be classified by reference to a chequer-board chart. The 56 O-groups were selected in 1968, mainly on the basis of 8 years' experience of UTI strains sent from this laboratory to the International Escherichia Center in Copenhagen for serotyping. The $\mathrm{O}$ groups were numbers $5,10-13,15,17,19-23,26,28,33,34,36,42,46,48,51,55,59,60,65$, $68,69,71,76-78,80-83,85,86,88,91,98,99,101,110,111,112$ ab, 112 ac, 115, 117-120, $125,128,133,140$ and 145 . There were also monovalent antisera against the O-groups 3,9 and 14.

Cultures that were non-specifically agglutinated by all 10 sera in the first step were classified as spontaneously agglutinating (autoagglutinable) and designated Sa. Often, but not always, such strains were growing with rough colonies on the Conradi-Drigalski plate. Strains that were not agglutinated by the available antisera and did not spontaneously agglutinate were designated $\mathrm{O} \mathrm{Na}$. Groupable and $\mathrm{O} \mathrm{Na}$ strains will together be referred to as smooth.

The final dilution of the antiserum in the wells was as a rule 1 in 500 to 2000 , usually 1 in 1000. At this dilution weak cross-reactions were sometimes seen, especially between groups $\mathrm{O} 1$ and $\mathrm{O} 2$ and between $\mathrm{O} 4$ and $\mathrm{O} 18$. The pattern of agglutination as observed in the microscope usually made titration unnecessary, large coarse agglutinates representing a strong reaction and small, even agglutinates a weak one. Weak spontaneous agglutination could sometimes be combined with a strong agglutination with one specific antiserum, most often the 014 antiserum.

Identification of the Kl antigen. The $\mathrm{K} 1$ antigen was assessed by a modification (Kaijser, 1977 ) of the serum agar technique (Bradshaw et al., 1971). The $\mathrm{K}$ typing was limited to antigen $\mathrm{K} 1$ since this is by far the most frequent $E$. coli $\mathrm{K}$ antigen and has been shown to be a virulence factor (Robbins et al., 1974; Kaijser, 1973; Kaijser et al., 1977).

Test for haemolysin production, Each colony to be tested was inoculated with a platinum needle on to an agar plate with $5 \%$ washed horse erythrocytes. The haemolytic zones were read immediately after overnight incubation.

Antibiotic sensitivity testing. Immediately after isolation, subcultures were subjected to antibiotic sensitivity testing with a disk diffusion method (Ericsson and Sherris, 1971) and the antibiotic disks described above. The medium was peptone-free nutrient agar with $5 \%$ defibrinated horse blood and the inoculum was rather light to facilitate reading of sulphonamide and nitrofurantoin inhibition zones. The prediffusion-time was $3 \mathrm{~h}$.

In 1975, minimum inhibitory concentrations (MICs) of the agents tested were assessed by the agar dilution method (Ericsson and Sherris, 1971). The medium used was PDM Antibiotic Sensitivity Medium (ASM) supplied by Biodisk and detailed by Wretlind, Nord and Wadström (1974). Plates ( $9 \mathrm{~cm}$ diameter) contained $25 \mathrm{ml}$ of ASM either without antibiotic or with serial twofold dilutions of the following substances: sulphasomidine, batch Sdg 1106 (Hässle-Ciba-Geigy, Basel/Mölndal), tetracycline HC1, batch 310-2973 (Pfizer, Täby), streptomycin sulphate, batch 53556-01 (Kabi, Stockholm), chloramphenicol, batch LPG 113 
(Parke-Davis, Stockholm), aminobenzylpenicillin-sodium, batch 260 (Astra, Södertälje), nitrofurantoin, batch T-8533 (Pharmacia, Uppsala), nalidixic acid, batch KL1770 (Winthrop, Stockholm) and trimethoprim, batch 88413-53 (Kabi, Stockholm). The inocula were applied with $0.001-\mathrm{ml}$ loops and consisted of broth cultures in the logarithmic phase of growth, diluted to give some 35 colonies on drug-free medium. The MIC was read as the concentration of the antibiotic that inhibited all visible growth of the strain under test. An exception was made for sulphasomidine and trimethoprim where microcolonies sometimes had to be disregarded because of the lag phase in the action of sulphonamide (Garrett and Wright, 1967). The MICs for E. coli K12 strain NCTC10538 were ( $\mu \mathrm{g}$ per ml): Su 16, T 1, S 1, C 2, A 2, Ni 2, Nal 1 and Trim 0.125.

Statistical calculations. Fisher's permutation test was used (Oden and Wedel, 1975). Two-tailed significance tests were done and values for $2 p$ of less than 0.05 were considered significant.

\section{RESULTS}

Thirty-six of the 771 cultures yielded very few colonies of Gram-negative bacilli or none at all. Thus, 735 colonies were picked off from the ConradiDrigalski plates, of which 709 were $E$. coli, eight Klebsiella, seven Citrobacter, four Enterobacter, five intermediary coliforms, one Proteus vulgaris and one Pseudomonas aeruginosa. The $709 \mathrm{E}$. coli colonies, each isolated from one Conradi-Drigalski agar plate, will be referred to as the unselected $E$. coli strains. Each of the six study groups, consisting of pupils from schools $\mathrm{A}$ and B in 1971, C and D in 1972, and B and D in 1974, contributed 99-134 unselected $E$. coli. Of these, 102 were resistant to one or more of the antimicrobial agents tested and 607 were fully sensitive.

Among the $E$. coli colonies picked off from the blood agar plates as probably resistant (see Methods), another 204 resistant strains were identified and will be referred to as the selected resistant $E$. coli. Two or more colonies with identical properties and isolated from the same specimen were regarded as belonging to the same strain.

\section{Sensitivity studies}

The MIC of each of the eight antimicrobial agents studied was determined for a random sample of 117 of the unselected $E$. coli strains (table I). The

TABLE I

Minimum inhibitory concentrations of eight antimicrobial drugs for 117 unselected strains of Escherichia coli

\begin{tabular}{|c|c|c|c|c|c|c|c|c|c|c|c|c|}
\hline \multirow{2}{*}{ Antimicrobial agent } & \multicolumn{12}{|c|}{$\begin{array}{c}\text { Number of strains for which the minimum inhibitory concen- } \\
\text { centration ( } \mu \mathrm{g} \text { per ml) was }\end{array}$} \\
\hline & $\leqslant 0.25$ & 0.5 & 1 & 2 & 4 & 8 & 16 & 32 & 64 & 128 & 256 & $>256$ \\
\hline $\begin{array}{l}\text { Sulphasomidine (Su) } \\
\text { Tetracycline (T) } \\
\text { Streptomycin (S) } \\
\text { Chloramphenicol (C) } \\
\text { Ampicillin (A) } \\
\text { Nitrofurantoin (Ni) } \\
\text { Nalidixic acid (Nal) } \\
\text { Trimethoprim (Trim) }\end{array}$ & $\begin{array}{l}\ddot{2} \\
\cdots \\
\cdots \\
\cdots \\
\cdots \\
\ddot{3} 9\end{array}$ & $\begin{array}{l}\cdots \\
\cdots \\
\cdots \\
\cdots \\
\cdots \\
\cdots \\
\dddot{48}\end{array}$ & $\begin{array}{r}70 \\
76 \\
4 \\
1\end{array}$ & $\begin{array}{r}36 \\
30 \\
48 \\
14 \\
2 \\
91 \\
5\end{array}$ & $\begin{array}{l}\cdots \\
\cdots \\
\dddot{64} \\
84 \\
26 \\
2 \\
\cdots\end{array}$ & $\begin{array}{r}3 \\
\cdots \\
2 \\
1 \\
18 \\
81 \\
\cdots \\
\cdots\end{array}$ & $\begin{array}{r}17 \\
3 \\
3 \\
\cdots \\
\cdots \\
8 \\
\cdots \\
\cdots\end{array}$ & $\begin{array}{l}45 \\
\cdots \\
4 \\
\cdots \\
\cdots \\
\cdots \\
\cdots\end{array}$ & $\begin{array}{r}29 \\
2 \\
2 \\
\cdots \\
\cdots \\
\cdots \\
\cdots \\
\cdots\end{array}$ & $\begin{array}{r}11 \\
2 \\
\cdots \\
\cdots \\
\cdots \\
\cdots \\
\cdots \\
\cdots\end{array}$ & $\begin{array}{l}1 \\
2 \\
\cdots \\
\cdots \\
\cdots \\
\cdots \\
\cdots \\
\cdots\end{array}$ & $\begin{array}{l}11 \\
\cdots \\
\cdots \\
\cdots \\
\cdots \\
\cdots \\
\cdots \\
\cdots\end{array}$ \\
\hline
\end{tabular}


TABLE II

Patterns of resistance shown by 306 faecal E. coli strains resistant to one or more of eight antimicrobial drugs*

\begin{tabular}{ll|ll}
\hline $\begin{array}{l}\text { Resistance } \\
\text { pattern }\end{array}$ & Number of strains & $\begin{array}{c}\text { Resistance } \\
\text { pattern }\end{array}$ & Number of strains \\
\hline SuTS & 87 & TSA & 3 \\
SuS & 55 & SuSC & 3 \\
T & 52 & SuTSNi & 2 \\
Su & 35 & SuSCA & 2 \\
TS & 20 & SuSA & 2 \\
SuTSA & 13 & SuT & 1 \\
SuTSCA & 8 & SuTSANi & 1 \\
SuTSC & 6 & SuTSCNi & 1 \\
A & 6 & SuTCA & 1 \\
Ni & 5 & TA & 1 \\
& & SA & 1 \\
\hline
\end{tabular}

* The abbreviations are explained in table $I$.

TABLE III

Demonstration of antibiotic-resistant $E$. coli in rectal swabs from 96 children who were examined both in 1972 and 1974

\begin{tabular}{lc|cc}
\hline $\begin{array}{l}\text { Number of children in } \\
\text { whom (in 1972) anti- } \\
\text { biotic-resistant } E \text {. coli } \\
\text { were }\end{array}$ & $\begin{array}{c}\text { Number of children in whom } \\
\text { (in 1974) antibiotic-resistant } \\
\text { E. coli were }\end{array}$ \\
\hline $\begin{array}{ll}\text { found } \\
\text { not found }\end{array}$ & $\begin{array}{c}\text { found } \\
\text { not found }\end{array}$ \\
\hline Totals & 99 & 16 & 21 \\
18 & 34 & 62 \\
\hline
\end{tabular}

highest MICs in the system used for $E$. coli of ordinary sensitivity were $(\mu \mathrm{g}$ per ml): Su 256, T 4, S 4, C 8, A 16, Ni 16, Nal 8 and Trim 2.

The patterns of resistance of $306 \mathrm{E}$. coli strains are given in table II; the data for 276 strains were obtained by agar dilution tests and the rest by disk diffusion tests performed at the isolation stage. Twenty-six selected resistant strains had died during the study. Four strains had apparently lost $\mathrm{R}$ factors. In a few cases, the presence of segregated $R$ factors was indicated; for instance O77 SuTSA- and SuSA-resistant bacteria occurred in the same specimen (Datta et al., 1971). In such cases, only the most complicated pattern of resistance was counted.

Resistance to $\mathrm{Su}, \mathrm{T}$ and $\mathrm{S}$, often in various combinations occurred most frequently. Altogether, 217 strains $(71 \%)$ were resistant to $\mathrm{Su}, 205(67 \%)$ to $\mathrm{S}$ and $196(64 \%)$ to $\mathrm{T}$. 
TABLE IV

$A$ comparison between $O$ antigen groups of antibiotic-sensitive, smooth E. coli strains and of strains resistant to at least one antibacterial agent

\begin{tabular}{|c|c|c|c|c|c|}
\hline \multirow{2}{*}{$\begin{array}{l}E . \text { coli } \\
\text { O group }\end{array}$} & \multirow{2}{*}{$\begin{array}{c}\text { Percentage } \\
\text { number of the } \\
\text { sensitive strains } \\
(n=534)\end{array}$} & \multirow{2}{*}{$\begin{array}{l}\text { Value of } 2 p \\
\text { for difference }\end{array}$} & \multicolumn{3}{|c|}{ Percentage number of the resistant strains } \\
\hline & & & $\begin{array}{c}\text { Total } \\
(n=281)\end{array}$ & $\begin{array}{l}\text { Unselected } \dagger \\
(\mathrm{n}=85)\end{array}$ & $\begin{array}{l}\text { Selected } \ddagger \\
(\mathrm{n}=196)\end{array}$ \\
\hline $\begin{array}{l}\mathrm{O} 1 \\
\mathrm{O} 2 \\
\mathrm{O} 6 \\
\mathrm{O} 8 \\
\mathrm{O} 18 \\
\mathrm{O} 25 \\
\mathrm{O} 77\end{array}$ & $\begin{array}{l}8 \cdot 8 \\
9 \cdot 2 \\
5 \cdot 2 \\
2 \cdot 8 \\
5 \cdot 4 \\
5 \cdot 1 \\
0 \cdot 4\end{array}$ & $\begin{array}{c}0.006 \\
<0.001 \\
0.02 \\
<0.001 \\
\text { NS } \\
\text { NS } \\
<0.001\end{array}$ & $\begin{array}{l}3.5 \\
1.8 \\
1.8 \\
9.2 \\
3.5 \\
2.1 \\
6.4\end{array}$ & $\begin{array}{l}1 \cdot 2 \\
3 \cdot 5 \\
2 \cdot 3 \\
3 \cdot 5^{*} \\
7 \cdot 0 \\
1 \cdot 2 \\
9 \cdot 3\end{array}$ & $\begin{array}{c}4.6 \\
1.0 \\
1.5 \\
11.7^{*} \\
2.0 \\
2.6 \\
5.1\end{array}$ \\
\hline $\begin{array}{l}\text { Not agglutinable } \\
\text { with the available } \\
\text { antisera }\end{array}$ & $23 \cdot 8$ & 0.002 & $34 \cdot 4$ & $29 \cdot 1$ & $36 \cdot 7$ \\
\hline
\end{tabular}

* Value of $2 p$ for difference here was 0.04 ; the differences between the other paired results in these columns were not significant (NS).

$\dagger$ Unselected $=$ picked from antibiotic-free medium.

$\$$ Selected $=$ picked because of antibiotic resistance.

Out of 190 strains resistant to the sulphonamide, 183 were not inhibited by $2048 \mu \mathrm{g}$ per $\mathrm{ml}$. Resistance to streptomycin in 185 strains was evenly distributed in the range 8-64 $\mu \mathrm{g}$ per $\mathrm{ml}$, whereas resistance to tetracycline in 176 strains was distributed bimodally, 50 strains being inhibited by $16 \mu \mathrm{g}$ per $\mathrm{ml}$ and 109 by $64-256 \mu \mathrm{g}$ per $\mathrm{ml}$. The high-level resistance group included 41 of $45 \mathrm{~T}$ monoresistant strains.

The 306 resistant $E$. coli strains were derived from 261 (33.9\%) of the 771 specimens. The range of variation in occurrence was $30 \cdot 3-37 \cdot 4 \%$ for the three years of the study and $24 \cdot 4-38.8 \%$ for the six study groups. In the two schools examined twice the prevalence of resistant $E$. coli did not change significantly. However, in school B resistance to T decreased from $31.1 \%$ in 1971 to $14.3 \%$ in $1974(2 p=0.003)$. Out of the 96 children from school $D$ who were examined both in 1972 and in 1974, 16 were shown to harbour antibiotic-resistant $E$. coli on both occasions (table III). Strains with identical properties were found on both occasions in three children. This figure coincides with the difference from the expected 13, calculated from $34 \times 37 / 96$ (table III).

The $\mathrm{O}$ and $\mathrm{K}$ antigens of the antibiotic-resistant and the sensitive $E$. coli strains were compared. The distribution of the most common $\mathrm{O}$ antigen groups and of non-agglutinable strains is shown in table IV. In the whole group of smooth, antibiotic-resistant $E$. coli strains the O-groups 1, 2 and 6 were less frequent than among the sensitive strains and the groups $\mathrm{O} 8$ and $\mathrm{O} 77$ were more frequent, as were strains not agglutinable with the available test sera. Ogroup 8 was more preponderant among the selected resistant strains than among the unselected.

Resistant E. coli serotypes $\mathrm{O} 8$ and $\mathrm{O} 77$ were found in all study groups. O8 bacteria appeared with 11 different patterns of resistance, from mono-resistances 


\section{TABLE V}

Occurrence of KI antigen in antibiotic-sensitive and -resistant unselected ${ }^{*}$ E. coli strains

\begin{tabular}{|c|c|c|}
\hline \multirow[b]{2}{*}{ O group } & \multicolumn{2}{|c|}{ Proportion of K1 positive strains among } \\
\hline & $\begin{array}{l}\text { antibiotic-sensitive } \\
\text { strains }\end{array}$ & $\begin{array}{c}\text { strains resistant to at } \\
\text { least one antibacterial } \\
\text { agent }\end{array}$ \\
\hline $\begin{array}{l}\text { O1 } \\
\text { O2 } \\
\text { O3 } \\
\text { O4 } \\
\text { O6 } \\
\text { O7 } \\
\text { O8 } \\
\text { O9 } \\
\text { O10 } \\
\text { O11 } \\
\text { O12 } \\
\text { O13 } \\
\text { O15 } \\
\text { O16 } \\
\text { O18 } \\
\text { O21 } \\
\text { O22 } \\
\text { O23 } \\
\text { O42 } \\
\text { O46 } \\
\text { O51 } \\
\text { O75 } \\
\text { O77 } \\
\text { O81 } \\
\text { O83 } \\
\text { O110 } \\
\text { O112 ab } \\
25 \text { other O groups } \\
\text { less than } 10 \text { of each }\end{array}$ & $\begin{array}{c}38 / 47 \\
34 / 49 \\
0 / 8 \\
2 / 10 \\
0 / 28 \\
10 / 19 \\
0 / 15 \\
1 / 3 \\
0 / 5 \\
0 / 3 \\
4 / 4 \\
3 / 24 \\
0 / 4 \\
11 / 11 \\
14 / 29 \\
0 / 13 \\
1 / 3 \\
0 / 27 \\
1 / 2 \\
1 / 2 \\
2 / 4 \\
1 / 12 \\
0 / 2 \\
1 / 9 \\
13 / 15 \\
1 / 1 \\
0 / 10 \\
0 / 48\end{array}$ & $\begin{array}{l}0 / 1 \\
2 / 3 \\
0 / 2 \\
0 / 3 \\
0 / 2 \\
0 / 3 \\
0 / 3 \\
0 / 1 \\
\dddot{1} / 1 \\
\dddot{0} \\
0 / 4 \\
1 / 2 \\
\dddot{6} / 6 \\
0 / 1 \\
0 / 1 \\
\ldots \\
\ldots \\
\ldots \\
0 / 8 \\
\dddot{101} \\
0 / 1 \\
\dddot{0} \\
0 / 18\end{array}$ \\
\hline $\begin{array}{l}\text { Subtotal, O groupable } \\
\text { Not agglutinable } \\
\text { Spontaneously } \\
\text { agglutinating }\end{array}$ & $\begin{array}{r}138 / 407=33.9 \% \\
1 / 127=0.8 \% \\
39 / 73=53 \cdot 4 \%\end{array}$ & $\begin{array}{r}11 / 61=18 \cdot 0 \% \\
0 / 24=0.0 \% \\
8 / 17=47 \cdot 1 \%\end{array}$ \\
\hline All & $178 / 607=29 \cdot 3 \%$ & $19 / 102=18.6 \%$ \\
\hline
\end{tabular}

* Unselected = picked from antibiotic-free medium.

$\mathrm{Su}, \mathrm{T}$ and Ni to multi-resistances SuTCA and SuTSA. O77 bacteria had eight different patterns, from mono-resistances Su and T to multi-resistances SuTCSA and SuTSA.

Table $\mathrm{V}$ shows the occurrence of the antigen $\mathrm{K} 1$ among the sensitive and the resistant unselected strains. The $\mathrm{K} 1$ antigen frequently occurred together with the $O$ antigens $1,2,7,16$ and 83 which were well represented among the sensitive strains. K1 was also common in the O18 strains, accounting for 6 of 11 resistant, smooth K1-positive strains. All the resistant $\mathrm{O} 18 \mathrm{~K} 1$ strains 
TABLE VI

Haemolysis in solid medium by antibiotic-sensitive and-resistant E. coli strains

\begin{tabular}{|c|c|c|c|c|}
\hline \multirow{3}{*}{ O typability } & \multicolumn{4}{|c|}{ Proportion of haemolytic strains among } \\
\hline & \multicolumn{2}{|c|}{ antibiotic-sensitive strains } & \multicolumn{2}{|c|}{$\begin{array}{l}\text { strains resistant to at least one } \\
\text { antibacterial agent }\end{array}$} \\
\hline & Number* & Percentage & Number* & Percentage \\
\hline Groupable into one of 69 & $76 / 407$ & $18 \cdot 6$ & $32 / 178$ & $18 \cdot 0$ \\
\hline Not agglutinable with the & $18 / 127$ & $14 \cdot 2$ & $3 / 93$ & $3 \cdot 2$ \\
\hline $\begin{array}{l}\text { avallable antisera (U Na) } \\
\text { Spontaneously agglutinating }\end{array}$ & $11 / 73$ & $15 \cdot 1$ & $2 / 23$ & $8 \cdot 7$ \\
\hline Total & $105 / 607$ & $17 \cdot 3$ & $37 / 294$ & $12 \cdot 6$ \\
\hline
\end{tabular}

* Number of strains showing haemolysis out of number tested in the stated category.

occurred in school D, four in 1972 and two in 1974, and all were mono-resistant to Su. Out of eight resistant Sa K1 strains, six were mono-resistant to Su and occurred in school D, four in 1972 and two in 1974. Altogether, the K1 antigen was found in $29 \%$ of the sensitive and in $19 \%$ of the resistant strains $(2 \mathrm{p}=0 \cdot 03)$.

The group of sensitive strains was compared with the entire group of resistant strains for the capacity to produce haemolysis in solid medium (table VI). Twelve strains that had died are excluded from the table. There was a tendency towards a greater proportion of haemolytic strains in the sensitive group $(17.3 \%$ compared with $12.6 \%, 2 \mathrm{p}=0.08)$. The $\mathrm{O} \mathrm{Na}$ sensitive strains were more often haemolytic than the $\mathrm{O} \mathrm{Na}$ resistant strains $(2 \mathrm{p}=0.009)$.

\section{Discussion}

In the present study of $E$. coli collected from healthy school-children during a 3-year period, the sensitive strains and the strains resistant to at least one antimicrobial agent were two somewhat different populations. Resistant strains were less likely than sensitive ones to belong to the $O$ groups 1,2 and 6 , and more likely to belong to the $O$ groups 8 and 77 or to be non-typable with the sera used.

Two possible virulence factors were unevenly distributed among sensitive and resistant $E$. coli. The $\mathrm{K} 1$ antigen was less common among the resistant strains. This antigen is of pathogenic significance, occurring more often in strains from UTI, especially pyelonephritis, than in strains from normal faeces (Kaijser et al., 1977) and is also strikingly common among $E$. coli strains causing neonatal meningitis (Robbins et al., 1974). In the large group of resistant strains not agglutinable with the O-antisera used, haemolytic strains were infrequent. Haemolytic capacity of $E$. coli in solid medium seems to correlate with ability to infect the urinary tract (Cooke and Ewins, 1975). 
Aspects of plasmid physiology offer possible explanations for a different distribution of properties among antibiotic-resistant and sensitive strains. Different cell envelope characteristics may confer different recipient abilities (Wiedemann and Schmidt, 1971). Plasmid incompatibility (Datta and Hedges, 1971) may be the reason for the low coincidence of haemolytic capacity and antibiotic resistance found among the $\mathrm{O} \mathrm{Na}$ strains of the present study.

The resistance factors selected by the use of antibiotics in animals and man both contribute to the maintenance of a pool of antibiotic-resistant enterobacteria that would otherwise tend to diminish (Swann Committee, 1969). Spread of hospital-derived, antibiotic-resistant enterobacterial strains from former patients to healthy people has been shown to occur (Damato, Eitzman and Baer, 1974). Also, animal E. coli strains may reach the human population via food (Cooke et al., 1970) and may become established in the bowel (Shooter et al., 1970).

In Sweden, chlortetracycline, oxytetracycline, bacitracin, spiramycin, oleandomycin, and the nitrofuran derivatives nitrovin, nitrofenid and nitrofurazon, are permitted feed additives for calves, swine, sheep and poultry (Statens Jordbruksnämnd, 1972). Tetracyclines are not permitted for growthpromotion purposes, but were so before 1 April 1971. The decrease in the prevalence of tetracycline resistance in school B from 1971 to 1974 is of some interest in this context. Chlortetracycline is the agent most used for group therapy with medicated feeds. Sulphonamides and streptomycin as well as penicillins are used extensively for individual antibacterial treatment in veterinary practice (Dr L. Rutqvist, personal communication). Sulphonamides are used as feed additives in other parts of the world (Jukes, 1971). More than $60 \%$ of the 306 resistant $E$. coli in the present study, were resistant to sulphonamides, and the frequency of resistance to streptomycin and tetracycline was similar.

Bettelheim et al. (1974), with full $\mathrm{O}$ and $\mathrm{H}$ serotyping facilities, found that O-typable strains were less commonly derived from animals and were more commonly derived from man. This is not surprising since the $E$. coli antigen scheme was based on work on strains of mainly human origin (Kauffmann, 1966). Serotypes commonly associated with UTI in humans, and probably derived from the normal human flora, were more often found among the human strains than among the animal strains.

Of antibiotic-resistant $E$. coli isolates from calves, Hartley et al. (1975) found that the O-groups 8,9 and 101 accounted for $24 \%$. In human clinical isolates, the O-group distribution differed between the antibiotic-resistant and sensitive strains (Petrocheilou and Richmond, 1976), groups 8, 9, 17 and 101 being considerably more common among the resistant $E$. coli, whether or not known to be carrying plasmids. These observations are in agreement with the concept that a high proportion of the antibiotic resistant $E$. coli found in our healthy school-children were animal-derived strains.

It is well known that during the months immediately following treatment of UTI, recurrences are most likely to occur (Winberg et al., 1974; Stansfeld, 1975). In that situation the composition of the normal E. coli flora might be of crucial importance. A selective pressure of antimicrobial substances, applied 
in a hospital milieu, may act upon a flora adapted to infect a sensitive human host (Lincoln et al., 1970). Antibiotic treatment of outpatients may also select for an $E$. coli flora resistant to one or more antibacterial agents. However, that flora will probably not be especially rich in factors likely to favour symptomatic reinfection of the urinary tract.

\section{SUMMARY}

During a 3-year period, 771 rectal swabs were taken from abacteriuric school-children. Out of $709 E$. coli strains, each isolated from one faecal specimen, 102 were found to be resistant to one or more antibacterial agents, and 607 to be fully sensitive. Another 204 resistant strains were found by selection for antibiotic resistance. The antibiotic-sensitive and the resistant strains were found to be two somewhat different populations, distinguished by a different distribution of $\mathrm{O}$ antigen types. Also, the $\mathrm{K} 1$ antigen was more common among the sensitive than among the resistant strains. Resistant strains that were not $O$ typable were very seldom haemolytic.

This work was supported by grants from the Medical Faculty of Göteborg, the Göteborg Medical Association, the First of May Flower Annual Campaign for Children's Health, and the Swedish Medical Research Council (Project no. 215). The skilful technical assistance of Helena Lomberg, Ingela Delgado, Siv Mangél, Lilian Nilsson, Kaety Plos and Anette Wetterstrand is very much appreciated.

\section{REFERENCES}

Bettelheim, K. A., Bushrod, F. M., Chandler, M. E., Cooke, E. M., O'Farrel, S. ANd SHOOTER, R. A. 1974. Escherichia coli serotype distribution in man and animals. $J$. Hyg., Camb., 73, 467.

Bradshaw, M. W., Parke, J. C., JR, Schneerson, R. and Robbins, J. B. 1971. Bacterial antigens cross-reactive with the capsular polysaccharide of Haemophilus influenzae type b. Lancet, 1, 1095.

Cooke, E. M. AND Ewins, S. P. 1975. Properties of strains of Escherichia coli isolated from a variety of sources. J. med. Microbiol., 8, 107.

Cooke, E. M., Shooter, R. A., Kumar, P. J., Rousseau, S. A. And Foulkes, A. L. 1970. Hospital food as a possible source of Escherichia coli in patients. Lancet, 1, 436.

Damato, J. J., Eitzman, D. V. AND BaeR, H. 1974. Persistence and dissemination in the community of R-factors of nosocomial origin. J. Infect. Dis., 129, 205.

Datta, N., Faiers, M. C., Reeves, D. S., Brumfitt, W., Ørskov, F. and Ørskov, I. 1971. R. factors in Escherichia coli in faeces after oral chemotherapy in general practice. Lancet, , 1, 312.

Datta, N. And Hedges, R. W. 1971. Compatibility groups among $\mathrm{fi}^{-} \mathrm{R}$ factors. Nature, Lond., 234, 222.

EDWARDS, P. R. AND EWING, W. H. 1972. Identification of Enterobacteriaceae, 3rd ed., Minneapolis.

Ericsson, H. M. AND Sherris, J. C. 1971. Antibiotic sensitivity testing. Acta path. microbiol. scand., Sect. B, Suppl. 217.

GARRETt, E. R. AND WRIGHT, O. K. 1967. Kinetics and mechanisms of action of drugs on microorganisms. VII. Quantitative adherence of sulfonamide action on microbial growth to a receptor-site model. J. pharm. Sci., 56, 1576.

HANSON, L. $\AA .1973$. Host-parasite relationships in urinary tract infections. J. infect. Dis., 127, 726. 
Hartley, C. L., Howe, K., Linton, A. H., Linton, K. B. and Richmond, M. H. 1975. Distribution of $\mathbf{R}$ plasmids among the O-antigen types of Escherichia coli isolated from human and animal sources. Antimicrob. Agents Chemother., 8, 122.

JUKES, T. H. 1971. The present status and background of antibiotics in the feeding of domestic animals. Ann. N.Y. Acad. Sci., 182, 362.

KAIJSER, B. 1973. Immunology of Escherichia coli: $\mathrm{K}$ antigen and its relation to urinarytract infection. J. infect. Dis., 127, 670.

KAIJSER, B. 1977. A simple method for K typing of E. coli bacteria. FEMS Letters, in the press.

Kaijser, B., Hanson, L. Å., Jodal, U., Lidin-Janson, G. and Robbins, J. B. 1977. Frequency of $E$. coli $\mathrm{K}$ antigens in urinary tract infections in children. Lancet, 1, 663.

KaufrmanN, F. 1966. The bacteriology of Enterobacteriaceae, Copenhagen.

LiNCOLN, K., Lidin-JANSON, G. AND WINBERG, J. 1970. Resistant urinary infections resulting from changes in resistance pattern of faecal flora induced by sulphonamide and hospital environment. Br. med. J., 3, 305.

LindBerg, U., ClaËsson, I., Hanson, L. A.. AND Jodal, U. 1975. Asymptomatic bacteriuria in schoolgirls. I. Clinical and laboratory findings. Acta paediat. scand., 64, 425.

MöLLER, A. J. R. 1966. Microbiological examination of root canals and periapical tissues of human teeth: methodological studies, Göteberg, p. 365.

Odén, A. AND Wedel, H. 1975. Arguments for Fisher's permutation test. Ann. Statistics, 3, 518.

Petrocheilou, V. and Richmond, M. H. 1976. Distribution of $\mathbf{R}$ plasmids among the $\mathrm{O}$-antigen types of Escherichia coli isolated from various clinical sources. Antimicrob. Agents Chemother., 9, 1.

Robbins, J. B., McCracken, G. H., Gotschlich, E. C., Ørskov, F., Ørskov, I. and HANson, L. A. 1974. Escherichia coli K1 capsular polysaccharide associated with neonatal meningitis. New Engl. J. Med., 290, 1216.

Shooter, R. A., Cooke, E. M., Rousseau, S. A. and Breaden, A. L. 1970. Animal sources of common serotypes of Escherichia coli in the food of hospital patients: possible significance in urinary-tract infections. Lancet, 2, 226.

StANSFELD, J. M. 1975. Duration of treatment for urinary tract infections in children. $B r$. med. J., 3, 65.

STATENS JORDBRUKSNÄMNDS CIRKULÄR No. 95. 1972, Stockholm (Circular from the National Agricultural Marketing Board).

Swann, M. M. 1969. Report of the Joint Committee on the use of antibiotics in animal husbandry and veterinary medicine, H.M.S.O., London.

Turck, M., Petersdorf, R. G. AND Fournier, M. R. 1962. The epidemiology of nonenteric Escherichia coli infections: prevalence of serological groups. J. clin. Invest., 41, 1760.

WiedemanN, B. AND Schmid, G. 1971. Structure and recipient ability in E. coli mutants. Ann. N.Y. Acad. Sci., 182, 123.

Winberg, J., ANDERSEN, H. J., Bergström, T., Jacobsson, B., LARSSON, H. ANd LinColn, K. 1974. Epidemiology of symptomatic urinary tract infection in childhood. Acta paediat. scand., Suppl. 252.

Wingerg, J., BergströM, T., Lincoln, K. AND Lidin-JANSON, G. 1973. Treatment trials in urinary tract infection (UTI) with special reference to the effect of antimicrobials on the fecal and periurethral flora. Clin. Nephrol., 1, 142.

WretLind, B., NoRD, C.-E. AND WADSTRÖM, T. 1974. In vitro sensitivity of isolates of Pseudomonas aeruginosa to carbenicillin, gentamicin, tobramycin, and some other antibiotics. Scand. J. infect. Dis., 6, 49. 